\title{
Ігар Жук
}

Grodzieński Uniwersytet Państwowy im. Janki Kupały (Białoruś)

Yanka Kupala State University of Grodno (Belarus)

E-mail: i.v.zhuk@tut.by

\section{У тумане Васіля Быкава: тры тэзісы да граматыкі наратыўнай інтрыгі аповесці}

We mgle Wasila Bykawa: trzy tezy gramatyki intrygi narracyjnej powieści

In the fog by Vasil Bykov: three theses to grammar of narrative intrigue of the prose

$\mathrm{H}$ а Дзявятых Гарадзенскіх чытаннях, якія праводзіла Гродзенская абласная навуковая бібліятэка імя Яуххіма Карскага ў гонар 90-годдзя $з$ дня нараджэння Васіля Быкава, высветлілася: цэнтр чытацкай увагі да творчасці вядомага беларускага пісьменніка апошнім часам змясціўся ў бок аповесці У тумане. Твор аказаўся найбольш запатрабаваным, і чытацкія фармуляры часцей за ўсё атрымлівалі пашпартны запіс менавіта гэтай аповесці. Ні „гродзенскі” цыкл быкаўскіх аповесцяў, што для кнігавыдач мясцовай бібліятэкі выглядала б зусім натуральным, ні хрэстаматыйна класічныя Сотнікаў ці Знак бяды, ні востра актуальныя па сацыяльным пафасе Сцюжа ці Аблава, ні спакуслівая па назве Пакахай мяне, салдацік - нішто з тых тэкстаў, якія са спадчыны пісьменніка несумненна сталі заслужанымі аўтарытэтнымі з'явамі літаратурна-духоўнага жыцця, апошнім часам не здолела скласці канкурэнцыю актыўнасці чытацкага попыту гэтай невялікай і не надта шматслоўнай аповесці.

Безумоўна, на чытацкія густы маглі паўплываць розныя акалічнасці. У тым ліку і бліскучая экранізацыя быкаўскага твора, здзейсненая рэжысёрам Сяргеем Лазніцам. Заслужанае прызнанне на міжнародным узроўні, набытае таленавітым экранным пераўвасабленнем, несумненна, паспрыяла папулярнасці твора. Але поспех кінаверсіі як поспех па-свойму лакальны, відаць, толькі падкрэсліў больш істотнае і важнае, што выступае асноўным: аповесць Васіля Быкава валодае не проста неабходным трывалым запасам самадастатковасці, а і некаторым яе лішкам. Твор нам дадзены пісьменнікам, што называецца, „навыраст”, і распазнанне яго патрабуе ад ненаіўнага чытача пастаяннага і некан'юнктурна- 
га духоўнага акту, акту таксама са збыткавым значэннем: пашырэння ўласных чытацкіх гарызонтаў у нечаканае вымярэнне. У вымярэнне, імя якому можна абазначыць - следам за Аляксеем Рэмізавым - як заданне ў „выглыбленне” («изглубление») пісьменніка. У дадзеным выпадку гаворка ідзе пра неабходнасць „выглыблення” Васіля Быкава. Гэта азначае так выбудаваць лінію ўзаемаадносін свядомасці творчай, аўтарскай, і свядомасці сустрэчнай, чытацкай, якая б выразна тлумачыла, чаму аповесць не проста не траціць чытача 3 цягам часу, але наадварот, пастаянна прываблівае да сябе і нават няўхільна нібыта прырашчае яго колькасць.

Адсюль і тры нашы крокі - тры тэзісы да праблемы спецыфікі наратыўнай інтрыгі.

\section{Тэзіс першы : заданне „выглыбіць” Быкава}

„Выглыбіць” («изглубить») у маім уяўленні азначае, з аднаго боку, значна „паглыбіць” з'яву: нырнуць у „лльббіню” самага-самага дна, чарпануць адтуль нявідныя $з$ надпаверхневай прасторы дадатковыя зместы, вымераць тую чалавеказнаўчую „глыбіню”, і з глыбінь „выгнуць” яе вонкі нязнаным для чытача чынам. А $з$ другога - самую з'яву творчай асобы пісьменніка ўбачыць як агромністую „глыбу”, дзе яго персанальная вялікаснасць і неспасцігальнасць прасвечана такім аб'ёмам універсальнага сведчання пра свет, у якой з лёгкасцю і сустрэчным чынам адклікаецца часцінка і нашага індывідуальнага вопыту.

Зразумела, для „выглыблення” сакрэтаў быкаўскай прозы не дастаткова задаволіцца толькі характарыстыкай самой інтрыгі, што закладзена ў сюжэце. Бо, несумненна, існуюць дадатковыя мастацкія маркеры, спосабы і прыёмы стварэння мастацкай карціны свету. Карэняцца яны не толькі ў непрадказальнасці фабульна-сюжэтных ходаў, не ў саміх канвульсіўных рухах мастацкіх перыпетый, нават не ў празмерным завастрэнні памежнай сітуацыі, калі ўстойлівасць чалавечых характараў і гуманістычных каштоўнасцяў, за імі замацаваных, залежыць ад самых мінімальных, ледзь прыкметных адступленняў героя ад маральнасці, зрухаў „ўлева-ўправа” ад цененькай нітачкі лініi дабра і справядлівасці. Дакладней, „маркеры” карэняцца і тут, i y̆ іх наяўнасці несумненна палягае пастаянства чытацкага інтарэсу да творчасці В. Быкава. Але палягае і у істотным дапаўненні таксама - у нечым вонкава няўлоўным, фабулярным чынам не перададзеным наўпрост, у наяўнасці некаторай дадатковай інтрыгі, якая не ўплецена ў сюжэт. Гэта значыць, ад інтрыгі самога расказвання - наратыўнай інтрыгі. Так званыя „лакальныя” быкаўскія аповесці, не маючы імклівага фабульнага дзейства і відавочнай дынамічнай інтрыгі, не разлічаныя на эпічны размах перыпетыяў, тым не менш не адпускаюць, а наадварот учэпіста трымаюць чытача на сваёй тэрыторы, бесперапынна трывожачы само „натруджванне” ўспрымальнай свядомасці, знерваванай і ўзбуджанай ад судакранання з чарговай, пераважна „франтавой старонкай”, яго твораў. Інтрыгуюць самі апавядацкія тэхнікі беларускага пісьменніка. 
Як гэта ні падасца дзіўным, але спецыфіка спосабу расказвання, які можна назваць наратыўнаю інтрыгаю, у В. Быкава шмат чым паўтарае нацыянальную ўласцівасць фабульна-сюжэтнай арганізацыі апавядальнага тэксту беларускай літаратуры ў яе традыцыйным абліччы.

Фабульная дынамічнасць, раскоша экстравагантных падзейных займальнасцяў увогуле не складае хоць колькі прыкметнай характэрнай рысы беларускай літаратурна-мастацкай традыцыі. Хутчэй, тут усё з дакладнасцю наадварот: традыцыю складае фабула рэдукаваная, паслядоўнае і выразнае яе паслабленне. Калі Якуб Колас, напрыклад, выпускаючы ў вялікі свет сваіх любімых „малазямельных" герояў, бласлаўляў іх сціплым аўтарскім сведчаннем: aб ix i песень не спявающь..., то гэта ўскосным чынам сведчыла і пра агульную ментальную ўстаноўку новага этапнага кроку ў гісторыі беларускай літаратуры цалкам. Тым самым сцвярджалася: літаратура, заснаваная на практычным ідэале (прыгожым выступае найперш тое, што само па сабе ёсць карысным), не павінна празмерна „,раскашэльвацца” на набыццё штучнага абгортачнага ўпрыгожання. Так, напрыклад, як разменьваюцца на набыццё ўпакоўкі пад дарагую заморскую цацку. „Цацка” сама мусіць быць самадастатковаю, мець забяспечаную эстэтычную каштоўнасць. Нават калі гэтая каштоўнасць някідкая вонкава і вонкава не надта эфектная.

I што мы бачым у Я. Коласа? Яго героі... жывуц̧ь $i$ долю смычуи̧ь иціха, // Дабра не бачачы з-за ліха. У знакамітай Новай зямлі не адбываецца нічога асаблівага, чым бы раптоўна ўскалыхнулася павольная плынь фабулы: штодзённая праца, пераезды-пярэбары 3 „гаспадаркі” на „гаспадарку”, новае уссталяванне побыту - і так нібы па крузе, пакуль смерць пана ляснічага востра не паставіла перад героямі твора задачу аб гарантыях уласнай сацыяльнай забяспечанасці: купіцьь зямлі, прыдбацьь свой кут, // Каб з панскіх выпутащциа пут. Вось, па сутнасці, і ўвесь сюжэтна-падзейны вузел, які паставіў герояў перад неабходнасцю разамкнуць звыклае семантычнае атачэнне і распачаць пошук свайго акрэсленага асабістага прадвызначэння ў гэтым вялікім свеце - пошук „прасторнага шляху" да новай зямлі-Айчыны.

А чым характарызуецца з пункту гледжання фабулярнай дынамічнасці яшчэ адзін анталагічна важны твор беларускай літаратуры - палеская трылогія Івана Мележа? Ды ўсё тым жа, яўнай неэкзальтаванасцю эпічных раманных фабулярных рашэнняў. Людзі проста спрабуюць выжываць на адпушчаным ім лёсам „востраве”, скоса ўзіраючыся ў гістарычныя завіхрэнні часу, парой, не вельмі рашуча спрабуючы абараніць сябе ад нялюдскасці яго патрабаванняў. А яшчэ захаваць стагоддзямі выпакутаваны, продкамі замацаваны і пранесены праз усе ліхаімствы нязломны прынцып стаічна-практычнай філасофіi: жbыць, як е. Як доля наканавала. Жыць.

Нічога экстрафабулярнага не знаходзім мы і ў іншых пачынальнікаў класічнай беларускай прозы: Ядвігіна Ш., Максіма Гарэцкага, Кузьмы Чорнага. I ў іх наступнікаў - аж да канца дваццатага стагоддзя. Хіба што мастацкая практыка Івана 
Шамякіна ды Ўладзіміра Караткевіча, для якіх займальная фабула па ўдзельнай эстэтычнай вазе была гэткай жа неабходнасцю, як і наяўнасць мускулістай побытавай мастацкай дэталізацыі, жэста ці падрабязнасці, успрымаецца тут некаторым добрым выключэннем. Ды яшчэ ўзорным напамінкам пра каштоўнасць кожнага ўрока ў засваенні вялікага мастацкага вопыту. Усё ж новая беларуская літаратура пачыналася ў дзевятнаццатым стагоддзі надта адмыслова - праз своеасаблівы, нідзе і нікім у бліжэйшым навакольным літаратурным асяроддзі, у тым ліку і ва ўласным, больш не паўтораным сюжэтна-фабульным эксперыментатарствам паэмы Тарас на Парнасе.

Гэта літаратура вельмі дзіўная, проза вельмі незвычайная. Яна, калі так можна сказаць, бездэтэктыўная. Вонкава яна пазбаўлена эфектнай падзейнасці, і разам 3 тым - уся шматпадзейная ўнутрана. Гэта калі пад падзеяй разумець шырокавядомае азначэнне дадзенай мастацкай катэгорыі, прапанаванае Юрыем Лотманам: падзея як перасячэнне персанажам межаў уласнага семантычнага поля. Акурат у такім сэнсе (як клубок напружаных узаемапранікальных семантычных палёў) апавядальная манера беларускай празаічнай традыцыі вызначаецца поліэвентуальнасцю, бо і сам свет беларускай прозы, пабудаваны ў пераважнасці на выяўленні ўнутраных, маральна-духоўных азначэнняў героя, пастаяннага выпрабавання яго чалавечай трывушчасці і грамадзянскай забяспечанасці. Падобна, фабулярная рэдукцыя, да чаго еўрапейская наратыўная традыцыя прыходзіла шляхам шматлікіх мастацкіх эксперыментаў, для беларускай літаратуры ў пэўным сэнсе ўяўляецца анталагічнай родавай прыкметай. Як і факт, што дзея самога расказвання (паводле Міхаіла Бахціна: событие рассказывания) для культурна-мастацкага коду ў гісторыі беларускай літаратуры ад самага пачатку і заўсёды мела больш адмысловае значэнне, чым яе эстэтычнае „візаві” - расказаная, распавяданая дзея.

Вось жа і ў быкаўскай прозе ўзяты пачатковы апавядальны „тон” традыцыйна не настроены на шпаркую пагоню за нечаканасцю сюжэтна-фабулярных рухаў. Нас чакае ўсвядомленая лакалізацыя дзейства, звужэнне і ўшчыльненне мастацкай прасторы, якая ўжо цяпер, ад самых першых сказаў, абцяжарана эмацыянальным адчуваннем будучай трэшчыны і будучага вывіху. А ў самой прасторы, як і ў лёсах яе насельнікаў, шырыцца прадвесце некаторага экзістэнцыйнага залому героя, так важнага для аналітычнай літаратурнай традыцыі. Можа быць, як ніхто іншы ў беларускай прозе 60-80 гадоў XX стагоддзя, В. Быкаў надзвычай строгі ў падсвядомай ахове складзенага характэрнага нацыянальнага почырку: лакалізуючы - аналізаваць. I ад гэтага - ад усвядомленай устаноўкі на выключэнне з уласнага мастацкага правіла афектыўнага „ажыўляжу”, ад падсвядомай абароны рацыянальных асноў мастацкага почырку беларускай літаратуры, ад дакладнага трапляння ў „пра-голас” сваёй літаратурай традыцыі, а разам з гэтым усім - трапляння і ў „пра-голас” культуры мастацкага выказвання еўрапейскай літаратуры, быкаўскай прозе наканавана незгасальна інтрыгуючая ступень чытацкай зацікаўленасці. 
У „пра-голас” яна трапляла і з іншай прычыны. Аддаючы перавагу тэхніцы сюжэтных рашэнняў перад фабулярнымі, В. Быкаў прыдаваў быццёваму абліччу нацыянальнай літаратуры моцны і свежы крэатыўны водбліск. У адной з гутарак 3 Алесем Адамовічам пісьменнік нібы мімаходзь зазначыў, што ягоны асабісты франтавы вопыт кепска адпавядае (!) ўласным літаратурным мэтам, а па сваёй крэатыўнай сутнасці сам ён - пераважна пісьменнік-,,сачыніцель”. Гэта значыць такі, якому хоць і не чужая праўда канкрэтнага факта, але перавагу ўсё ж схільны аддаць дакладнасці і сіле мастацкага вымыслу. I нават, азіраючыся на пройдзены творчы шлях, быў вымушаны акцэнтавана падкрэсліць: „ваенная” проза ў нечым абмяжоўвала яго творчую волю. Бой ён і ёсць бой, жыццёвая прастора катэгарычна звужана шмат чым: і найпершай экзістэнцыйнай патрэбай уратавацца, і такой жа экзістэнцыйнай неабходнасцю не скарыцца абставінам, не адступіць і не здрадзіць - перамагчы. Дый нават абавязкам перад вайсковым статутам і жорсткай, без усякага ўжо выбару, вымушанасцю падпарадкавацца даведзенаму ці, наадварот, недаатрыманаму загаду. „Ведаеш, - звяртаўся пісьменнік да А. Адамовіча, - гэта ўсё мала цікава - баі, скажам. Ну што там? Агонь, смерць. Ты не бачыш, хто цябе забівае, завошта? Так сказаць, ананімная смерць. Літаратуры патрэбны псіхалагізм, а тут які псіхалагізм, калі няма выбару..." I дадаваў, здавалася б, вельмі нечаканае: „Іншая справа - партызанская рэчаіснасць, калі ў ёй не шукаць вялікую праўду. Сумніўная гэта справа - шукаць праўду на вайне [...] як пачынаецца вайна, першаю яе ахвяраю падае праўда. Але ў іншых адносінах партызанка дае большыя магчымасці...”2.

Становіцца відавочным, што паварот пісьменніка да партызанскай тэматыкі, нават больш - устойлівая і настойлівая ўвага да яе, дыктаваліся не недахопам матэрыялу ці вонкавай патрэбай да яго абнаўлення, а складвалася ва ўстойлівы творчы прынцып. Пісьменнік на цвік павесіў франтавы шынель і надоўга перабраўся ў партызанскую зямлянку з канкрэтным мастацкім жаданнем: пашырыць прастору для „сачыніцельства”. Відаць, у гэтай прасторы лакальнай партызанскай аповесці яму і бачылася найбольш адэкватна магчымасць вырашэння важнейшай для яго ідэйна-мастацкай задачы, якую сам пісьменнік тлумачыў выразна і недвухсэнсоўна: „Мяне цяпер і заўжды мучыла, калі можна так сказаць, праблема свабоды. Найперш свабоды асобы. Яе залежнасць ад соцыўма, ад палітыкі, ад праклятых акалічнасцяў жыцця"з.

Прызнанні Быкава, тут пададзеныя, важныя не толькі сваёй непасрэднаю аўтарскай падказкай, якая расшыфроўвае пастаянную ў быкаўскай творчасці перафакусіроўку ўвагі з „франтавой” старонкі на старонку нефрантавога ваеннага быцця. Яны важныя яшчэ і тым, што актуалізуюць значную і вялікую, эстэтычна

S. Szapran, Wasil Bykau - Aleś Adamowicz. Maładyja hady. Autabijahraficznyja dyjałogi W. Bykawa z A. Adamowiczam, „Dziejasłou”, nr 3, 2014, s. 198.

2 Ibidem.

3 Ibidem. 
каштоўную праблему „выглыблення” В. Быкава, практычна абыдзеную ўвагай сучаснай літаратурнай навукі - праблему, якую я называю прыблізна як граматыка вымыслу.

Пад дадзеным мастацкім феноменам умовімся разумець не проста даследчую метафару, а вельмі канкрэтную з'яву з устойлівымі паняццевымі дамінантамі. Граматыка вымыслу, як, зрэшты, і ўсякая граматыка, падразумявае кіраванне аўтарскай творчай воляй разнастайнымі камбінацыямі адзінак мастацкага выказвання, якія праяўляюцца праз інтрыгу самога акту расповяду дый у цэласнасці адлюстраванай наратыўнай карціны свету наогул. Як і якія камбінацыі мастацкіх адзінак падпарадкоўваюцца волі аўтарскага расказвання, паназіраем за тым (вядома, не поўна, яшчэ толькі ў накідавым плане) на прыкладзе аповесці У тумане. Тым больш, што менавіта гэтая аповесць у параўнанні з іншымі „партызанскімі” аповесцямі В.Быкава мае павышаную тэндэнцыю да падкрэсленага „сачыніцельства”.

\section{Тэзіс другі: эфект пазнавальнасці Быкава У тумане, або чым так важная дыскурсія „чужароднасці” ў аповесці}

Па чым пазнаецца Васіль Быкаў у гэтым творы?

Перш за ўсё цэнтральнай алегорыяй туману. Бо туман, гэта - штосьці архетыпна глыбокае з разраду нацыянальнай канцэптасферы, 3 такім узмацненнем семантычных канатацыяй і валентнасці семантычных спалучэнняў, у якіх выразна праступае гістарычны воблік этнічнага быцця.

Натуральна, і мастацкі свет, абазначаны вехамі туманнага стану, будзе ў чымсьці істотна Быкава паўтараць, узнаўляць, а ў чымсьці, наадварот, супрацьстаяць яму акурат па шкале мастацкага кіравання першаэлементамі тэксту.

А таму чытаем аповесць няспешна.

„Слотным ветраным днём позняй восені на другім годзе вайны атрадны разведчык Бураў ехаў на станцыю Масцішча, каб застрэліць свайго знаёмца Сушчэню"4.

Звыкла, зачыны твораў Васіля Быкава нейтральныя, нават знарокава нейтральныя да фабулярнай інтрыгі. У іх, у зачынах, змяшчаецца, зразумела, быкаўская інтэнцыя да напружанасці, алюзія на яе і яе прадвесце. Але ніколі апавядальная анакруза ў Быкава наўпрост не ўтрымлівае паказальную стрэлку на вузлавы семантычны цэнтр інтрыгі сюжэтнай.

У тумане - відавочнае выключэнне. Тут усё як у тумане: нечакана самая першая фраза (а яна цалкам змясцілася ў абзац, што таксама не зусім характэрна для архітэктонікі быкаўскай манеры выказвання) пазначыла незваротную зададзенасць дзейства - адразу накіравала да кульмінацыйнага ядра: маецца адбыц-

\footnotetext{
4 W. Bykau, U tumanie. Apowiesci, Minsk 1989, s. 5.
} 
ца расправа над здраднікам, чакаецца смерць, і смерць гэтая мэтавая, зусім не „ананімная”.

Тым самым фраза сваё адпрацавала - па сутнасці, гэта згорнуты тэкст твора, канкрэтна дадзенага, ці яшчэ якога-небудзь, быкаўскага, ці не. Але важна іншае. Перад намі тэкст, прынцыпова самадастатковы, ён гэтак жа прынцыпова і завершаны. Ён пазнавальны і выразна паказвае на прысутнасць у ім быкаўскай аўтарскай свядомасці. Пазнаецца нават тое, што гэты Быкаў - Быкаў позні. Тэкст пачынае гаварыць сам за сябе, а таму яшчэ раз звернемся да працытаванага фрагмента.

Слата „позняй восені” - мадальна ўстойлівы эмацыйны канцэпт быкаўскай версіі мастацкага часу. Так павінна быць найчасцей: слата, бездарожжа, зазімак, першы снег, халадэча - на зямлі пустальга, дзе, здаецца, няма хоць колькі спрыяльных умоваў для раскашавання жыцця. Чытаем Быкава-,паслясямідзясятніка": слата у Знаку бяды, суцэльная сцюжная аблога ў Cцүюжы, дый Cотнікай, Пайсиі $і$ не вярнуцица, Дажыцьь да світання - скрозь заснежаны, завеяны, слатлівы пачатковы прастор.

Ды і ранейшыя творы, незалежна „франтавыя” ці „партызанскія”, інтанацыю расказвання з самага пачатку прыбіраюць ў той жа мадальны канцэпт слаты:

Праклятая вышыня:

Мы адступалі.

Надвор'е выдалася такое, што горш і не прыдумаеш: увесь дзень ішоў дождж напалам са снегам. Не падсохлая яшчэ ад вясновага разводдзя зямля зусім раскісла, гразь на дарозе перамяшалася са снегавой кашай, у якой агідна хлюпалі нашыя змакрэлыя ногі ${ }^{5}$.

\section{Яго батальён:}

Траншэя была мелкаватая, пад пахі, не болей, сухая і пыльная. Каб не дужа вытыркацца з яе, Валошын звыкла аблягаўся грудзьмі на бруствер, расставіўшы ў бакі локці. Аднак доўга стаяць так, згорбіўшыся, пры ягонай высокай мажнай постаці было не надта каб зручна, мяняючы позу, камбат незнарок варухнуў локцем, і мёрзлы камяк зямлі з глухім стукам скаціўся ў траншэю ${ }^{6}$.

\section{Сотнікаў:}

Яны ішлі праз лес глухой, замеценай снегам дарогай, на якой не было ні чалавечага следу, ні каляіны, ні нават знаку ад капыта ці полаза7

5 W. Bykau, Zbor tworau u 4-ch tamach, t. 4. Minsk 1982, s. 5.

6 Idem, Zbor tworau u 4-ch tamach, t. 2. Minsk 1981, s. 282.

7 Ibid., s. 133. 


\section{Пайсиі і не вярнуциа:}

Ішоў снег. Белая гушчэча сняжынак коса неслася долу, з ціхім няспынным шолахам засыпаючы сухую ад марозу траву, рудыя зараснікі асакі на балоце. Гладкімі плямамі браліся ўмерзлыя вадзяныя прагалы, якія, каб не пакідаць слядоў, старанна мінала Зоська ${ }^{8}$.

\section{Умоўна бясхмарна пачыналася хіба Трэияя ракета:}

Я ляжу ў акопе на разасланым шынялі і доўга гляджу ўгору, у сінюю бездань летняга неба. На паверхні ціха - ні стрэлу, ні выбуху, наўкола ўсе спяць; трохі далей, ля снараднай нішы, нехта моцна сапе, здаецца, вось-вось пяройдзе на храп. Дзень стаіць ветраны, спёка не дужа вялікая, сонца схавалася за бруствер і кіруе ўжо на захад9.

Вось і аповесць У тумане цалкам прытрымліваецца прыблізна такіх жа колераў і фарбаў - творчая воля пісьменніка пачувае сябе найбольш спадручна. Добрая прывязка да „сачыніцельства” адразу заявіла пра сябе ў выбары і месца дзеяння, і героя дзеяння: „,атрадны разведчык Бураў”. „Партызанка” як эквівалент творчай нязмушанасці і на гэты раз трывала бярэ ў палон агульную наратыўную ўстаноўку пісьменніка.

У чым яшчэ з безумоўнасцю „пазнаецца” Быкаў, дык гэта ў канкрэтызацыі гістарычнага часу дзеяння: „на другім годзе вайны”. Быкаў у сваёй творчасці (пісьменніцкай, а не кінематаграфічнай) „ваюе” вельмі далёка ад пераможнага Берліна. Світання перамогі яго героям часцей за ўсё не відно; яно нават не праглядваецца ніводным сполахам. Усё тая ж „слата”, няпэўнасць, плыткасць. А няпэўнасць і калючая золкасць „слаты” сацыяльнай, гістарычнай, падвышаючы патрабаванне да індывідуальнага запасу трываласці асобы, прымушаюць актуалізавацца прынцыпы, ужо зараней закладзеныя ў натуру чалавека. Яны цяпер самы надзейны суб'ектыўны компас. Бо калі наперадзе ёсць пэўнасць, ёсць выйсце ці хаця б бачнасць выйсця, - тая бачнасць, тая пэўнасць і тое выйсце могуць стаць вышэй за ўласную духоўную загартаванасць. I ўжо не сам чалавек ідзе, а яны вядуць чалавека праз абставіны, вядуць, часам, памылкова, зманліва, звыродна. Ды толькі чалавек ім, гэтым прывідным сляпучым прыкметам надзеі, давярае больш, чым уласным унутраным - устойлівым, правераным і перададзеным ад шматлікіх папярэднікаў - арыенцірам. Яно так, зрэшты, і лягчэй, і прасцей, і даступней, калі не сам адказваеш за нешта; за цябе гэта робіць усё той жа сляпучы пробліск надзеі, а самому застаецца толькі паслухмяна ісці следам.

А „на другім годзе вайны” - які ж пробліск? Нічога з пэўнасцю не вядома, нічога не ясна і не прадбачыцца, што і куды павернецца. Спадзяванне толькі на тое,

\footnotetext{
8 W. Bykau, Zbor tworau u 4-ch tamach, t. 3. Minsk 1982, s. 117.

9 Idem, Zbor tworau u 4-ch tamach, t. 1. Minsk 1980, s. 104.
} 
што грунтоўна закладзена ў табе часам ранейшага папярэдняга сталення. I вось Бураў, ,атрадны разведчык”, сунецца „слотным ветраным днём позняй восені”, маючы цвёрдым імператывам загад ,застрэліць свайго знаёмца Сушчэню”.

Вось тут, самым злёце кадэнцыі ўступнай фразы, Быкаў як быццам пярэчыць сабе і выпрацаваным творчым прыёмам мастацкага асэнсавання рэчаіснасці. Дагэтуль ён ніколі не паказваў мэты, тым больш канчатковай, у вандраванні героя праз непамыснасць складзеных абставінаў. Бо што для развіцця фабулы азначае „застрэліць Сушчэню”? Па сутнасці, гэта азначае спыніць самую аповесць: дарога скончана, мэта ясная, фінал прадбачны. Інтрыга памірае, і разам з ёй 3 не меншай пэўнасцю безнадзейна памірае твор: Сушчэня будзе забіты, і смерць набудзе сваё аблічча. Мы ніколі ад пачатку не ведаем у Быкава, ці выратуецца ад фатальнай трагедыі Глечык, ці адшукае патрэбную сцяжыну ў Трыест Іван Цярэшка, ці адаб'ецца ад шквалу варожых атак закінуты ў кукурузным полі адзінокі гарматны разлік, што будзе з Рыбаком і Сотнікавым, як складуцца лёсы Антона Галубіна і Зосі Нарэйкі, лейтэнанта Іваноўскага і капітана Валошына, сям’і Багацькаў, Хведара Роўбы, ці адшукае неабходныя доказы Агееў, раскопваючы кар'ер сваёй памяці і т.д. Мы таго ніколі не ведаем ад пачатку, і нават больш за тое, перагарнуўшы апошнюю старонку, можам не знайсці адказу, сустрэўшыся з мастацкім эфектам адкрытага фіналу. Творчая воля аўтара супрацівіцца падобнаму веданню. У тумане ж заяўлена адразу і без хістанняў: Сушчэня павінен быць забіты.

Сэнсавы імператыў уводнага выказвання, як бачым, адназначны. Аднак насцярожвае адна маленькая акалічнасць: той Сушчэня быў колісь „знаёмцам” атраднаму разведчыку Бураву. Замёрлая інтрыга пачынае адраджацца - усё ж заб'е ці не заб'е?

Мы зноў мусім вярнуцца да тэксту быкаўскай аповесці, і хай даруецца зацягнутая тэкставая цытата - яна важная. Тут адбываюцца вельмі значныя і знакавыя працэсы пабудовы ініцыятыўных сэнсаў, з якіх неўзабаве і складзецца граматыка быкаўскага апавядальнага дыскурсу:

„Гэты Сушчэня быў тутэйшы вясковы мужык, яшчэ $з$ давайны рабіў на чыгунцы, але месяц назад, будучы арыштаваны за дыверсію ля Выспянскага моста, купіў сабе жыццё тым, што выдаў саўдзельнікаў, сваіх жа чыгуначнікаў, якія памаглі яму развінціць рэйкі. Хлопцаў павесілі ў мястэчку, а Сушчэню выпусцілі, i ён другі тыдзень раскашаваў пад носам у гарнізона, у сваёй ладнай дамоўцы ля станцыі, у цяпле і сытнасці, мабыць, думаючы, што партызаны да яго не даберуцца. Даруюць яму. Але такое не даруецца, такое належала пакараць. Камандзіры ў атрадзе параіліся і мінулае ноччу паслалі Бурава зрабіць тое, чаго немагчыма было не зрабіць. Каб Бураву было ўпраўней, яму ў дапамогу далі партызана Войціка, і яны ўдвух на змораных конях, адмахаўшы якіх кіламетраў трыццаць лесавога шляху, таго ж дня надвячоркам прадраліся праз гушчарысты ўзлесак на поле за які кіламетр ад Масцішча"10.

10 W. Bykau, U tumanie, s. 5. 
„Гэты Сушчэня”, „раскашаваў”, „ладная дамоўка”, „пакараць” - чыё гэта слова, чыя свядомасць такім спосабам заяўляе пра сябе? Ды відаць жа, не таго аб'ектыўнага апавядача, што інфармаваў пра заданне атраднага разведчыка. Свядомасць тут іншая, чужая - ананімна-калектыўная свядомасць, што без усякага сумнення прыпісала грэх здрадніцтва чалавеку, замацавала за ім гэты грэх („такое не даруецца") і цяпер гнала праз увесь слотны ветраны дзень Бурава для справядлівай расправы.

Tое, што аповесць пачынаецца „чужым” словам, словам няўласна аўтарскай свядомасці, важна найменей з дзвюх прычын. Па-першае, так ствараецца атмасфера ідэалагічнага „туману”, дзе ўсё заснавана на прыродзе вербальных міфаў. Міфам, як вядома, вераць без лішніх довадаў. Сказалі: здраднік - значыць, здраднік, чаго тут лішне разбірацца. Сушчэню „належала пакараць” і тым самым здзейсніць суд самае справядлівасці.

Але „чужое слова”, уведзенае Быкавым знарокава падкрэслена (стылістыка тут цалкам чужая для пісьменніка), важнае яшчэ і з тае прычыны, што сам аўтар цераз „чужую” ананімную - „камандзірскую” - свядомасць („камандзіры параіліся") дыстанцуецца ад безапеляцыйных прысудаў, характэрных для калектыўных свядомасных міфалагем. Для яго гэта яшчэ вялікае пытанне, што там здарылася на чыгунцы, а галоўнае ў паліцыі: здрадзіў, ці не? Выдаў ці не выдаў? Бо характэрны для Быкава апавядацкі стылістычны код пачынаецца толькі з апошніх некалькі слоў, якімі заканчваецца другі абзац: Бураў і прыдадзены яму Войцік надвячоркам прадраліся праз гушчарысты ўзлесак на поле за які кіламетр ад Масиішча.

„Прадраліся”, „гушчарысты ўзлесак” - як жа адрозніваецца па дакладнасці дэталізаванай назіральнасці, па рытме выказвання дый па сінтаксічна-інтанацыйнаму напаўненню выказвання ад абагуленых і бязлікіх праяў „камандзірскай” свядомасці: „раскашуе”, „у цяпле і сытасці”, „не даберуцца”.

Нарэшце, трэба зазначыць, што сапраўдны „пазнавальны” Быкаў-апавядальнік пачынаецца толькі з наступнага, трэцяга абзаца аповесці: „У лесе дык ужо змяркалася; сцюдзёны туман і раннія прыцемкі паглыналі змакрэлы сасоннік, амаль голы, з рэштаю зрудзелага лісця падлесак, а на палявым прасцягу за гразкай гравійкай было яшчэ светла..." ${ }^{11}$. Тут уся стылістыка - непасрэднае слова прамога, тыпова быкаўскага выказвання. Уводнае супрацьстаянне розных свядомасцяў закончылася, сітуацыя саслізнула з кручка статычнай кропкі - фабульная інтрыга кранулася да сваёй, здавалася б, семантычна заканамернай развязкі. Быкаў пачынае дазнанне, якое, аказваецца, таксама закончыцца словам „чужым”, словам татальнага адчужэння.

Аповесць У тумане фінал мае алегарычны: байцы з іншага партызанскага атрада, ідучы на заданне, чуюць у густым тумане сухі шаўчок адзіночнага рэвальвернага стрэлу. Але паколькі ім самім нішто не пагражае непасрэдна, то і да

11 Ibidem. 
падазроных гукаў яны адносяцца як да „не-сваёй” - чужой і непатрэбнай, лішняй ім - рэальнасці. Маўляў, не сур'ёзнае і нават трагічнае нешта адбываецца ў лясной гушчэчы, а так, пустое, чым прабаўляецца „дурань нейкі”.

Прысуд, першапачаткова вынесены чужой „камандзірскай свядомасцю” (Сушчэню як здрадніка - расстраляць!), атрымлівае яшчэ больш злавеснае акалічнаснае ўвасабленне: нявольныя і нечаканыя завочныя сведкі гібелі Сушчэні партызаны $з$ іншага атрада - не сумелі ўчуць вялікай трагедыі і тым самым умуравалі яшчэ адзін бяздушны камень у высозна непераадольную сцяну вымусовай адчуджанасці чалавека ад сваёй праднаканаванай быццёвай прыналежнасці. Тое для іх, як аказалася, - пустая і нявартая ўвагі забава „дурня”.

Утвараецца, такім чынам, адмысловая наратыўная рамка, суцэльнае кола „чужаслоўя”, што экспрэсіўна афармляе ў аповесці мастацкую алегорыю „затуманенай” сацыяльнай свядомасці, татальнай адчуджанасці, чужасці і чужароднасці ўсяго да ўсяго. У той жа час, падобна, інтуіцыя „сачыніцельства” падказвала В. Быкаву: аповесці, каб не страціцца, патрэбна эстэтычная супрацьвага. Злу татальнай чужароднасці павінен супрацівіцца іншы эстэтычны феномен, не такі аднагалосны ў свёй сацыяльнай скіраванасці. Твору неабходна трымацца за нешта контрапунктнае, па семантычнаму, кампазіцыйнаму, фармальна-мастацкаму рашэнню больш дынамічнае і гнуткае, чым проста суцэльная змрочная канцэнтрацыя ліха. Патрабаваўся яшчэ адзін дадатковы магутны апавядальны дыскурс, які нават самім спосабам расказвання гісторыі мог бы адмыслова сведчыць на карысць рознароднасці і неаднапалярнасці светабудовы.

\section{Тэзіс трэці: кантрапунктная поліфанія}

\section{А) Кантрапункт сну.}

Ад каго ў спадчыну Васіль Быкаў атрымаў паэтыку снабачанняў - пытанне, вядома, рытарычнае. Культуралагічны кантэкст такой традыцыі агромністы. Але ў быкаўскай граматыцы вымыслу сны, трызненні, псіхалагічныя экзерсісы на мяжы рэаліі і па-над рэальнасці - рыса, не проста надзвычай устойлівая. Яна з эстэтычнай „мецінкай”. Героі беларускага пісьменніка, дарэшты „натруджаныя” брутальнай непасільнасцю навакольных абставін, перамяшчаюцца ў прасторы якраз праз такую ўласцівасць - праз пераадоленне сном мяжы ўласнай семантыкі. У рэаліі мастацкага свету яны досыць аседлыя і маларухомыя, затое па-за ілюзіяй такой рэаліі яны - скрозь дынамічныя.

Ёсць і дадатковае аблічча ў падобнай „мецінкі”. Пісьменнікам з метафізічнай экзістэнцыйнай устаноўкай ды яшчэ прыхільнікам строгага лапідарнага стылю вельмі няпроста ўнікнуць адной тэхнічнай пісьменніцкай пасткі. Задаючыся пытаннем пра межы і ролю сну ў мастацкім творы, Мілан Кундэра трапна сфармуляваў пэўную тэхналагічную супярэчнасць у пісьменніцкай працы: „Сон - гэта ўсяго толькі ўзор таго мастацкага вымыслу, які я лічу самым вялікім дасягнен- 
нем сучаснага мастацтва. Але як убудаваць некантралюемае уяўленне ў раман, які, па азначэнні, абавязаны ўяўляць сабой свядомае (усюды курсіў аўтара. - I. Ж.) даследаванне быцця? Як спалучыць гэтыя надта разнародныя элементы?”"2.

Звычайна, анейрычная семантыка схіляе працэс літаратурна-мастацкага апавядання пераважна ў адзін з трох напрамкаў: або ў бок прадракання будучага лёсу героя, або як наратыўны мосцік да тлумачэння пэўных сітуацый, звязаных з раскрыццём ідэйна-мастацкіх рашэнняў твора, або як разнавіднасць алегоры, што ў іншасказальнай форме перадае ўнутраны свет дзейнай асобы.

Але Васілём Быкавым сон, ці, як кваліфікаваў тое Ю. Лотман, „семіятычнае вакно”, скарыстоўваецца найперш дзеля актыўнага аголенага „остранения” сэнсаў. Рэч у тым, што мастацкае сненне адлюстроўвае нешта такое, што ў бытавым плане страціла першапачатковую каштоўнасць: яно ўсё - у мінулым.

Парадокс Быкава ў тым, што ён „страчаныя” каштоўнасці вяртае і вяртаннем сваім перакульвае апрыёрыку дадзенай мастацкай рэальнасці. 3 гэтага моманту ўсё нібы наадварот. Тое, што разгортвалася перад чытачом як рэалія, набывае значэнне каштоўнасці, адыйшоўшай у прошласць, а тое, што было пройдзеным, становіцца голасам, які кліча наперад, голасам з будучыні - гэта значыць адклікаецца такімі духоўнымі каштоўнасцямі, якія яшчэ не зацверджаны вопытам. Вярнуць і сцвердзіць іх яшчэ толькі належыць. Звычайна ў В. Быкава аксіялагічныя ўстаноўкі сноў перададзены таму персанажу, з якім звязаны асноўны фокус назірання - фокуснаму персанажу.

У аповесці ж У тумане - тры працяглыя трывожныя сны, роўна столькі, колькі налічвае фабульная інтрыга асноўных дзейных асоб. Натуральна, што і мастацкая аксіялогія тых сненняў розная.

Так, смяротна параненаму Бураву трызніцца яго даваенная машына-,,палутарка", якая падае ў нейкую прорву, і ніхто не ў стане спыніць яе некантраляваны пагібельны рух. Самым агульным чынам сон прачытваецца як метафарычнае прадраканне немінучага трагічнага лёсу героя. Але паверхневае нацяжэнне тэксту не вельмі „прагінаецца” пад відавочнасцю i, часткова, банальнасцю першаснага тлумачэння падобнай алюзіўнай падказкі. Сон-трызненне Бурава, па ўсёй вераемнасці, завязаны на больш значныя аўтарскія канатацыі. Невыпадкова пісьменнік плаўна пераключае чытацкую ўвагу з ілюзорнай плыні апавядання (сон-трызненне) у плынь фабульна гістарыйную (снабачанне-ўспамін). Праз „палутарку” мы дадаткова паглыбляемся ў фактуру папярэдняга жыцця Бурава, а галоўнае - у факт супраціву-помсты, які здзейсніў Коля Бураў, агрэсіўна не прымаючы акупацыйныя парадкі. Такім чынам, Быкаў не проста ўскладняе эмацыйна-эстэтычную функцыю абранага ўстойлівага мастацкага прыёму, але і падкрэслена вылучае сваё адмысловае бачанне праблемы: помста помсце - розніца. Адна справа - сляпая і паслухмяная „помста”: знішчыць невядома ці вінаватага Сушчэню, гэта значыць, помста віне недаказанай. I зусім іншая справа - помста

12 M. Kundera, Iskusstwo romana, Sankt-Pietierburg 2014, s. 106. 
фашысцкім паслугачам, дзе ўсё відавочна, і прэзумпцыі невінаватасці быць не можа, што называецца, па азначэнні. Так - сітуацыйна, псіхалагічна, кантэкстуальна - матывуецца апошні бураўскі наказ Войціку: „Сушчэню не чапаць!”

Наадварот, Войціку не трызніцца нічога. Яму проста сніцца працяг некаторай рэчаіснасці, дзе, бадай, самай значнай каштоўнасцю выступае партфель. У бюракратычнага профілю яго вечка гарантыяй устойлівасці і сацыяльнай абароненасці адбіваецца для Войціка і мінулае, і будучыня. За „партфель” варта трымацца з усіх сіл - філасофія „, няпэўнага чалавека” і „раённага стратэга” (як іранічна характарызуе яго Бураў: „ён усё разумеў інакш, і такі абачлівы, як раённы стратэг"13), з надзённай рэчаіснасці арганічна перавандроўвае ў рэчаіснасць анейрычнай прасторы. Адзінае, што выбіваецца 3-пад умоўна-рэальнага часу і прасторы ў гэтым сненні сваёй вымысленасцю - пакладзеныя ў блішчасты партфель яйкі, „сасніць якія, паводле вясковага павер'я, азначала трапіць у бяду"14. 3 гэтакай аўтарскай падказкі, (аўтарскай таму, што прыведзенае толькі-што выказванне ёсць прамым аўтарскім голасам; „літаратурнаму” ж Войціку сказаць так: 'паводле вясковага павер'я', эстэтычна недаступна), з падказкі, што завяршала сон літаратурнага героя і азначала яго „абуджэнне”, і пачынаецца ўзмоцненае ўшчыльненне мастацкай сімволікі „туману”: „3-пад хвой на прагаліну поўз золкі туман..."15.

Зазначу наперад, што ў аповесці алегарычная „туманнасць” хранатопу акурат і звязана пераважна з гэтым персанажам. „Няпэўны чалавек” ёсць чалавекам „туманным”, чалавекам 3 нетрывалай асновай надзеі. Той жа Бураў ад самага пачатку шкадуе, што „звязаўся з такім напарнікам, але, мабыць, лепшага не знайшлося, мусіў паехаць 3 тым, каго далі”'16. I калі шкадаванне Бурава першапачатковым семантычным штуршком нагадвала тыповасць быкаўскай мастацкай сітуацыі (адзін з герояў-напарнікаў мусіць быць забяспечаны меншай жыццяздольнай трывушчасцю), то выхад апавядальнага дыскурсу са снабачання ў „золкі туман” „позняй восені другога года вайны” абазначаў зусім інакшую ступень мастацкага абагульнення. Войцік - гэта не зменшаны спалячаны „войт”. Гэта - калі працягваць іменную вербальную гульню - наадварот, маленечкі „савецік”, „туманны савецікус", штучны прадукт штучнага грамадскага часу. Бо савецкаму перыяду грамадскага развіцця з яго сюррэалістычнасцю сацыяльнай міфалогіi, 3 яго несапраўднасцю і штучнасцю найлепшае метафарычнае азначэнне акурат і склала б метафара туману. У ім, у сацыяльным тумане з намераным скажэннем адбіткаў рэальнасці, - i выток невыноснай трагічнасці, і замаруджаная запозненасць гістарычнага развіцця, і знак нашае супольнае бяды.

13 W. Bykau, U tumanie, s. 6.

14 Ibid., s. 71.

15 Ibidem.

16 Ibid., s. 6. 
Нарэшце, трэці сон - сон Сушчэні, героя з адпачатковай функцыяй поўнага закладніка абставін. Яго сон разгортваецца ў дастаткова спецыфічных эстэтычных абставінах: ля сканалага ад ранення Бурава і ў атачэнні несціханага каркання гругановай стаі, што няўмольна пераследавала горстку людзей ў тым змрочным туманным лесе. Месца ў В. Быкава пазначана з яшчэ больш выразнай экспрэсіяй ірацыянальнай семантыкі: з золкатуманным лесе. I без таго ірацыянальная рэчаіснасць, калі адно няшчасце кліча наступнае, згушчаецца, здаецца беспрасветна, і ў гэтакім беспрасвецці скрыўленай да безвыходнасці прасторы нечакана мяняецца вобразная семантыка ўмоўнага месца дзеяння. Спакваля нараджаецца яшчэ адна магутная вобразная алюзія. Алюзія, праз якую прасочваецца вялікая гістарычная дыстанцыя культурнага мастацкага мыслення чалавецтва. Мы памятаем, што расстрэльваць Сушчэню адвялі у „ельнічак”, а лес, асабліва лес яловы, у чалавечай свядомасці назаўсёды захаваў водсвет міфалагічнага светаадчування. У яго змрочнай і непраходнай, безжыццёвай гушчэчы ў імя нараджэння новага паўнапраўнага чальца грамадскай супольнасці здзяйсняецца ў міфе выпрабавальны абрад ініцыяцыі. Той, хто зможа пераадолець выпрабаванні і выстаяць, атрымлівае права на далейшы жыццядайны працяг; каму ж выпрабаванне аказвалася не пад сілу, назаўсёды пакідаў род чалавечы.

Вось і ў Быкава сітуацыя падобная да міфалагічнай: у „золкатуманным лесе” трое мужчын праз сны ці хваравітыя трызненні спавядаюцца перад вечнасцю роду чалавечага. Што ім сніцца ў хвіліну, калі сам-насам знаходзяцца перад знакамі гэтае вечнасці, з чым яны „прачынаюцца”, каб выйсці далей у жыццё? „Сушчэню не чапаць!” - гэта фінальны наказ Бурава. Чалавек у апошнюю хвіліну свайго зямнога існавання змог усё ж да нечага даўмецца, і сваёй немінучай смерцю спрабаваў знойдзеную ісціну сцвердзіць яшчэ ў гэтым жыцці. Войціку пасланы дрэнны знак: яйкі ў партфелі сведчылі адназначна, што выпрабаванне аказалася непасільным. А што Сушчэню прарочыла ягонае „абуджэнне”?

Сушчэня прахопліваецца ад пачутага ў сне крыку: спалохана крычыць яго маленькі сын Грышачка. I тое ў нейкай ступені ўспрымаецца як працяг рэчаіснасці. Бо Грышачка быў першым, хто, не ўсведамляючы, сустрэў знак неадступнай бяды, што пераступіла парог іхняй хаты разам з Буравым. Грышачкаў плач, які чуе Сушчэня у сне, справакаваны працягам рэчаіснасці і цяпер - злавесным лямантам гругановых армад. Крумканне груганоў „ачалавечваецца”, „рэінкарнуецца” ў трывожны сынаў крык. Крычыць дзіця. Дзіця плача. У імя чаго яно надрываецца?

У імя чаго і наша ўспрымальная свядомасць растрывожана не столькі сном, які мы бач ы м, але і прабуджэннем, якое ч у е м ?

У Быкава адказ застаецца 3 межамі апавядальнай кампетэнцыі аповесці. Ясна і зразумела адно: вядома ж, дзіця плача не на добрае, а на злую неадчэпную ліхую бяду. Кантрапункт сну галоўнага героя ва ўсёй наратыўнай стратэгіi твора першым чынам і адказваў за перанясенне трывожнага прадчування бяды на тэрыторыю чытацкай свядомасці. А разам з тым і за моцнае, адчувальнае, 
эмацыйна ўплывовае выражэнне аўтарскай інтэрвенцыі ва ўвесь працэс „сачыніцельства".

Б) Кантрапункт шляху.

Філасофія бяды ў творы Васіля Быкава неад’емна злучана з матывам шляху. А больш дакладна - лабірынту. Некуды ў тым „тумане” трэба ісці чалавеку, але куды?

„Куды ісці яму на гэтым свеце, ён не мог ніяк сцяміць”17, - зазначае аўтар пра „недарасстрэленага” Сушчэню. Недзе засталася недакапаная ім і незакрытая ўласная яма-магіла, а гэта ў народным разуменні надта кепскае прадвесце. Трэба было б знайсці ватоўку: холадна, у слаце „позняй восені” застынуць нядоўга. Але там, дзе засталася ватоўка, можа чакаць паліцэйская засада. Хадзіць жа па дарогах наогул небяспечна: „дарог Сушчэня баяўся - 3 дарог цяпер ішла ўся бяда”18.

Калі Кузьма Чорны ў адным з лепшых сваіх раманаў Млечны илях па-філасофску адлюстроўвае ўчадзелую ад ваеннага дыму планету, дзеля чаго на той планеце ў адно месца збірае ў прадымленым „тумане” некалькіх герояў з рознай нацыянальнай і сацыяльнай прыналежнасцю - пры ўсёй вонкавай безвыходнасці, у тых герояў усё ж заставалася арыенцірам высокае неба і сімволіка млечнага шляху на ім. У Сушчэні ж і таго няма: „I ён, растапырыўшы рукі, слепа брыў, адхінаючыся ад голля, часам прытрымліваючы шапку на галаве"19.

„Слепа” брыдзе чалавек у Васіля Быкава. Матыў „сляпой” і гразкай дарогі ў творчасці В. Быкава складае вельмі ўстойлівую прыкмету яго вобразнай паэтыкі. Ужо ў самай першай, што імгненна прынесла заслужаную вядомасць аўтару, аповесці Жураўліны крык байцы абараняюць не што іншае, а дарогу - чыгуначны пераезд. Цяжкая і небяспечная, з трагічным завяршэннем дарога да волі ў альпійскіх уцекачоў італьянкі Джуліі і беларуса Івана Цярэшкі (Альпійская балада). Хлюпаткая, разбітая да невыноснасці ў непраходнае месіва стаптаным кірзавым ботам стомленага працаўніка вайны - пехацінца дарога ў Праклятай вышыні, Здрадзе, Пастизы. На стылай зімовай дарозе чакае сваёй апошняй хвіліны лейтэнант Іваноўскі (Дажыць да світання). Снежныя суметы партызанскіх дарог вядуць да ўзвышэння Сотнікава і ліквідацыі Рыбака (Сотнікаў). Пошукі дарогі звязваюць і такія творы, якія быццам непасрэдна і не стасуюцца з уласным франтавым вопытам: той жа Сотнікаў, Пайсці і не вярнуцица, Воуччая зграя, Знак бяды, Кар 'ер, Сцюжа, Аблава, Балота. І зноў жа толькі Трэияя ракета з тых ранейшых „франтавых старонак” была ў В. Быкава самай „бездарожнай”, самай нерухома-акопнай. Але і там матыў дарогі праявіў сябе не толькі прозвішчам адмоўнага героя (Лёшка Задарожны), але і дрыготкім успамінам Лазняка з часоў акупацыі пра дарогу, вымашчаную чалавечымі целамі пад гусеніцамі варожых танкаў.

17 Ibid., s. 26.

18 Ibid., s. 27.

19 Ibidem. 
Мабыць, нездарма гэта ў В. Быкава. Ва ўсіх выпадках - чалавек на жыццёвай дарозе, але да чаго, да якіх высноў і жыццёвых каштоўнасцяў яна давядзе чалавека?... Вось чаму ў вялікай праблеме чалавека і сутнасці яго існавання быкаўскім пяром пракрэслена важнейшае быційнае пытанне, якое можна сфармуляваць як пытанне нейтральнай хвіліны. Пісьменнік даводзіў, што такіх, нейтральных хвілін, не бывае. Кожная з іх у залежнасці ад абставін мяняе чалавека. Яна не абавязкова робіць яго лепшым ці горшым - яна выяўляе яго сутнасць, яго духоўную стойкасць. I з гэтых маленькіх мікрасутнасцяў быцця ўрэшце і складаецца вялікае чалавечае права на зямное існаванне.

Але тут, У тумане, дарога „сляпая” скрозь, лабірынт - як бясконцы тупік. Гэта, зноў жа, толькі „ненадзейнаму” „раённаму стратэгу” Войціку выхад на шлях здаецца збавеннем. Да яго ён імкнецца ўсімі сіламі, не ведаючы яшчэ, што менавіта на дарозе, акурат пры пераходзе праз шашу-гравійку і надарыцца яго смяротная хвіліна. А пакуль у „золкатуманным лесе” яго грэе іншае адчуванне: „Гэтую лесавую дарожку ён трохі запомніў з учарашняга, паселішчаў быццам нідзе не было, i, мабыць, яму можна пакуль не баяцца" ${ }^{20}$. Ва ўсіх жа астатніх выпадках шлях азначае знікненне ў смура-бялесай паласе „туману” рэальных абрысаў і нават поўнае растварэнне прасторавага аб'ёму - хоць колькі рацыянальная экзістэнцыя становіць сабой невырашальную праблему, голасу жывога чалавека няма тут месца. I вось ужо воляю аўтара Сушчэня павінен спавядацца ў сваёй невінаватасці перад нежывым целам, трупам Бурава: мёртвы - паверыў, а жывыя?... Тым больш, што сітуацыйная спіраль у сваёй ірацыянальнасці раскручваецца ў некантралявым для аднаго чалавечага лёсу брутальным напрамку: і немцы загналі пастку, і свае адмаўляюцца верыць!

Адзінае, што хоць 3 большага нагадвае некаторую падобнасць рацыянальнага, гэта тугі вузел узаемазалежнасцяў. Каб выжыць усім траім, яны на пэўным этапе разгортвання мастацкай калізіі патрэбныя адно аднаму. Бураву патрэбен „ненадзейны” Войцік, каб канваіраваць недастрэленага Сушчэню. Войціку патрэбен Сушчэня як здаровы дужы мужчына, каб валачы цяжкое цела смяротна параненага Бурава. Сушчэню патрэбен Бураў як адзіная надзея на вераемнасць апраўдання і адзіна магчымы ахоўны талісман. Але і гэтая матываваная ўзаемазалежнасць у аснове сваёй мае анамальны пасыл. Яна справакавана ні чым іншым, як неназванай пазакадравай „камандзірскай свядомасцю”, і жудаснасць моманту ў тым і палягае, што канчатковае вырашэнне сітуацыі залежыць іменна ад тых, хто яе справакаваў адпачаткова - ад той жа ананімнай і сляпой „камандзірскай свядомасці”. Лабірынт выхаду з „туману” не мае, - маральна-філасофская тэза, навеяная быкаўская граматыкай „вымыслу”.

Ды і вырашаецца дадзеная сітуацыйная тэза вельмі своеасабліва. Пакуль усе трое - Сушчэня, Бураў і Войцік - адчуваюць узаемную неабходную залежнасць, кампазіцыйны крой аповесці наладжаны на лінеарны (паслядоўны) тып

20 Ibid., s. 35. 
сюжэтна-фабулярнага развіцця - па нейкай прамой. Ці, больш дакладна, па адным напрамку ўказальнага вектара. Калі ж гэты персанажны „трыюмвірат” яшчэ не складзены (эпізод падрыхтоўкі да расстрэлу Сушчэні: кожны заняты нечым сваім ў асобным пункце мастацкай прасторы), або, наадварот, „тройка” распадаецца пад напорам абвостранай сюжэтнай інтрыгі, актуалізаванай гібеллю Бурава, кампазіцыя, падобна, мяняе пачаткова абраны лінеарны прынцып. Цяпер аповесць выстройваецца поліфанічным парадкам: фабульнае забяганне наперад і вяртанне да вытокавага моманту, шматслойныя паўтарэнні, паралельнасць сноў і трызненняў герояў, ушчыльненне зрокавага складніка сітуацыі праз падвоенае, a то і патроенае назіранне і нават нешта блізкае да ітэрацыйнай хады аповяду, калі, упёршыся ў ірацыянальны тупік „туманнага” хранатопу, аповед нібы зноў пачынаецца з зыходнай кропкі, але ўжо з новым фокусным персанажам. Усё гэта творыць ілюзію густога сінтэзаванага існавання геройнага свету. Кожны герой нясе роўную долю адказнасці за рух сюжэта, і кожны герой у тым нялюдскім лабірынце, шукаючы выйсце, трымаецца сваёй выратавальнай „сценкі”.

Што ж фіксуецца пісьменнікам ў гэтакім, суцэльна „сляпым” кантрапункце шляху? Ідэал „сачыніцельства” у Васіля Быкава шчодра пакідае свае знакі. Дарога - адна, а лініі на ёй - як з неперасякальнымі значэннямі. Не перасякаюцца яны не столькі таму, што з дыяметральным паваротам самае распавяданай гісторыі (цяпер няма актуальнай неабходнасці аднаму быць расстрэленым, а другім - яго расстрэльваць) мяняецца і ступень фабулярнай залежнасці герояў, колькі $з$ іншай прычыны. Сама „геаметрыя” мастацкай прасторы аповесці $У$ тумане адмаўляе магчымасць падобнага перасячэння. I пачынаецца ўсё задоўга да распаду сюжэтнай залежнасці тройкі вядучых дзейных персанажаў.

Ёсць у аповесці як бы непрыкметны, але моцна сімвалічны пачатковы эпізод. Каб дабрацца да дому „здрадніка” Сушчэні, Бураву і Войціку трэба знайсці кладку праз невялікую рачулку, што пераразае іх дарогу і тым самым замінае ім. Што, якія „берагі” злучае тая кладка, навошта наогул пісьменнік акцэнтуе ўвагу на ёй?

Бураў, пераходзячы кладку, паслізнуўся. Войцік „пераехаў больш удала”21. Трохі пазней па ёй жа будуць канваіраваць і Сушчэню, які „пройдзе” ўпэўнена і трывала. Ствараецца відавочная канцэнтрацыя вобразных пасылаў для іншасказальнага, алегарычнага прачытання побытавай, здавалася б, дэталі: кладка злучае не берагі невялікай воднай перашкоды, а наадварот, пачынае выконваць кантрастыўную функцыю. Злучаючы лёсы трох чалавек, яна ўадначассе і размяжоўвае аксіялагічна - на тое, што нейкім чынам „пражыта” к гэтаму моманту, і тое нялюдскае, што „пражыць” яшчэ належыць. Нават пачынае сімвалізаваць іх лёсы: першым, як мы ведаем, $з$ жыццёвай кладкі „саслізнуў” Бураў.

Такім чынам, рачулка з кладкай, шаша з яе прадчуванне немінучай бяды, незакрытая яма-магіла - вось актыўныя мастацкія маркеры ў кантрапункце шляху, што і выгінаюць пракудна „геаметрыю” быкаўскай аповесці, робячы яе мастац-

${ }^{21}$ Ibid., s. 11. 
кую прастору неперасякальнаю для ўзаемнасці геройных лёсаў, падзяляюць яе на часткі „да" і „пасля”: пэўнай вызначанасці быцця $\partial а$ выхаду на Сушчэнеў двор і новай быццёвай якасці пасля такога кроку.

Адзінае, што „геаметрыю”прасторы быкаўскай аповесці аб'ядноўвае, гэта густое сімвалічнае покрыва туману.

\section{В) Кантрапункт туману}

Усе беды, - мы памятаем, - думае Сушчэня, ідуць ад дарогі.

Чаму так? Чаму паратунку варта шукаць не на шляхах-магістралях, што, па ідэі, павінны былі б падказваць на супакаяльную сувязь 3 людскім светам i, значыць, нешта гарантавана станоўчае абазначаць, а наадварот, ісці трэба ад дарог, $а$ д уяўнай гарантыі, $а д$ свету ў цэлым? Чаму ад адваротнага ўсё ў быкаўскай аповесці?

Ды, відаць, таму, што ўвесь гістарыйны імператыў быкаўскага твора таксама пабудаваны на з'яве адваротнасці. У аповесці сама чалавечая катастрофа - са знакам адваротнасці. Яна завяршаецца не толькі сухім шчаўчком пісталетнага стрэлу ў тумане, што падводзіў рысу фізічнага існавання Сушчэні. Рэальная катастрофа адбылася нашмат раней. Яшчэ нават моманту, калі Бураў, гнаны „камандзірскай свядомасцю", пераступіў парог Сушчэневай хаты. Для усіх, у тым ліку і для самаго абвінавачанага, „здраднік” Сушчэня ўжо мёртвы. Не ведае таго толькі сынок Грышачка, даверліва паказваючы Колю Бураву свае дзіцячыя цацкі. А ў дарослых „цацкі” больш складаныя. Таму і заходзіцца ў зняможаным крыку дзіця ў Сушчэневым сне: „камандзірская свядомасць” ужо сваю злую ролю выканала - засталася толькі адна „тэхніка” давядзення распачатага да свайго канца.

Толькі - ці да лагічнага? Якая логіка ўвогуле падзей, створаных адмысловым пісьменніцкім стаўленнем да рэчаіснасці, якую Быкаў кваліфікаваў „сачыніцельствам"?

Логіка тут адна, вынесеная ў загаловак аповесці: логіка туману.

Бо туман - гэта абазначэнне невыразнасці бачання прадметаў рэчаіснасці, што часта прыводзіць да памылковасці, а то і адваротнасці іх разумення.

Туман - гэта і метафара забыцця, прошласці, мінулага наогул (у Быкава ж наадварот, містыка туману найперш змяняе час цяперашні, час мастацкага дзеяння).

Туман - гэта і сумненне, і выпрабаванне, і выпрабаванне сумненнем.

Туман - гэта і шлях, i, як бачна, найчасцей шлях у лабірынце.

Увогуле туман - гэта не атмасфера, а семантычны заменнік некаторай ўстойлівай формы экзістэнцыі, звыродліва-анамальнага існавання ды намерана выяўленай ірацыянальнай рэчаіснасці, дзе ўсё акурат наадварот. Катастрофа чалавечага лёсу і яе вырашэнне знаходзяцца ў адваротнай залежнасці. У адваротнай залежнасці і бяда, і шлях выратавання з яе. Адваротны вынік „камандзірскіх” распараджэнняў: Сушчэня не расстраляны, забітым аказаўся, наадварот, Бураў; Войцік, які займаўся канваіраваннем і наглядам, сам трапіў у пастку безагляднай неасцярожнасці і трапіў у паліцэйскую засаду. Нават тое, жывы недастрэлены 
Сушчэня цягне на сабе мёртвае закасцянелае цела Бурава, спавядаецца перад ім - усё з адваротным знакам канатацыі: адпачатковая несвабода вязня валачэ на сваіх плячах прывід „свабоды” выканаўчай волі, асуджаны стараецца для свайго свайго ката, а, значыць, - 3 павышанай сілаю мастацкага абагульнення - быццё 3 апошніх сілаў цягне ношку не-быцця. Куды ўжо большай ступені ірацыянальнасці даводзіцца чакаць у мастацкім творы!

Туман у мастацкай сістэме быкаўскай аповесці - скразны кампазіцыйны вобраз. Ён - слотны і пранізлівы сімвал той ірацыянальнай пасткі, у якую аказаліся заманенымі ўсе дзейныя асобы. А таму надта заўважны з першых старонак аповесці: „сцюдзёны туман і раннія прыцемкі паглыналі змакрэлы сасоннік, амаль голы, з рэштаю зрудзелага лісця падлесак, а на палявым прасцягу за гразкай гравійкай было яшчэ светла...”22. Асабліва падкрэсленай функцыя туману праяўляецца ад моманту сноў-трызненняў літаратурных персанажаў.

Вось прачынаецца Войцік: „З-пад хвой на прагаліну поўз золкі туман, ахінаў дрэвы, кустоўе, вогла слаўся па травяным доле, спрэс затуляў блізкае лясное наваколле". ${ }^{23}$ Вось прахопліваецца са сну Сушчэня, абуджаны знясіленым Грышачкавым плачам: „Лежачы пад хваінай, ён трохі паслухаў; не, чалавечага голасу або плачу нідзе не было чываць, толькі блізка, над самай прагалінай, абурана каркалі вароны, чуваць было, мітусіліся, варушыліся, пераляталі з хвоі на хвою, нібы чагось абурана патрабуючы ад чалавека, i Сушчэня са злоснай рашучасцю вылез 3-пад хвоі. На прагаліне ўсё было воглым і стылым ад начнога дажджу і туману, які цяжкім нізкім покрывам спрэс сунуўся ў хвойніку, затуляў неба і дальняе вяршалле дрэў”24. А вось ужо яны удвух, 3 нялюдскай ношай закасцянелага Бурава на Сушчэневай спіне, кранаюцца неўзабаве ў далейшую дарогу: „Наўсцяж усёй прасекі, па лесе між камлёў старых хвой і ў падлеску курэў слотны туман, вяршалле дрэў угары хавалася ў яго плыўкіх ірваных пах. Відаць было недалёка, на якіх паўсотню крокаў...”25. „Яны доўга брылі так па золкатуманным лесе, астуджана дыхаючы яго густа спіртавым водырам. Абсыпаны ігліцай дол у бары быў мяккі і чысты, ісці па ім было лёгка і нячутна, верхавіны высачэзных хвой хаваліся ў нізкай туманнай навалачы, неба амаль не было відаць; рэдкі падлесак з параснікаў бярэзніку, ядлоўцаў і хвоек таксама ціха стаяў, ахутаныя клоччам туману"26.

I так - па меры набліжэння да шашы - ледзь не на кожнай старонцы: „Туман не знікаў увесь дзень, мо трохі парадзеў надвячоркам...”27; „Вецер у гары, мабыць, патроху суняусся, так і не разагнаўшы туман, які ці не стаў нават гусцець на сконе дня, за час іх чакання. Так, туман пагусцей, Войцік адзначыў гэта па

22 Ibid., s. 5.

${ }^{23}$ Ibid., s. 71.

24 Ibid., s. 75.

25 Ibid., s. 78.

26 Ibid., s. 79.

27 Ibid., s. 81. 
тым, як у шэрай навалачы здаля закурэў падлесак 28 ; Цямнела, аднак, марудна. Белаваты туман хвалямі расплываўся па лесе, асядаў зверху і насоўваўся нізам, змрокам і сцюжай ахінаючы голае кустоўе падлеску, цёмнае куп'ё маладых хвоек паблізу"29.

Метафара туману замгляе не мінулае ці будучыню - туманам В.Быкаў густа ўкутвае цяперашнасць, час дзеяння герояў, пра які вядзецца аповед. А час гэты - мы ўжо ведаем - складаецца з затрыманай ў сваім развіцці катастрофы чалавечага лёсу.

Канечне ж, пісьменнік свядома загушчае туман, знарокава прапісвае яму функцыю самастойнай дзейнай асобы, свядома падкрэслівае умоўную вымысленасць мастацкай сітуацыі. Усё гэта, безумоўна, так. Але ў імя чаго? Што такой умоўнасцю, падкрэсленай аж да празмернасці, хоча пісьменнік падказаць чытачу? Якая мастацкая задача, духоўна важная і па-філасофску значная, вырысоўваецца $з$ падвышанай ўмоўнай сімволікі „навалачы туману”?

Вяртаючыся да прыведзенай вышэй гутаркі пісьменніка з Алесем Адамовічам, варта згадаць: Быкаў пратэстуе супроць смерці, як ён называў тое, ,ананімнай”, смерці ў нічым, аднекуль напатканай, нічога за сабой, акрамя факту смерці, не азначанай. Смерць як і жыццё, калісьці сцвярджаў пісьменнік у Яго батальёне, павінна нешта сцвярджаць або нешта адмаўляць - хутчэй за ўсё у стасунках 3 паняццем вышыні чалавечнасці. „Ананімная” ж смерць - ці на старонцы „франтавой” аповесці ці ў аповесці „партызанскай” - змяшчае надта нязначную вагу чалавеказнаўчай інфармацыі для пісьменніка.

У такім кантэксце зададзімся пытаннем: што значыць той фінальны стрэл, які „ў тумане” чалавечай катастрофы, запаволенай і нават затрыманай у імклівасці свайго падзейнага развіцця творчай воляю мастака, падводзіць рахунак жыццю недарасстрэленага „здрадніка”? „Ананімная” гэта смерць ці не, калі прынятая яна не ад кулі тайнага ці адкрытага ворага, а ўчынена свядома і са сваёй рукі?

Вось тут і дзейнічае падвышаная алегарычная семантыка кантрапункта туману. Калі браць пад увагу толькі факт таго, што Сушчэня, загнаны ў кут неспрыяльнай сілай абставін („Вот палучаецца, - горасна думае ён, - што немцам вераць, а свайму чалавеку - не...”зо), усвядомлена зводзіць рахункі $з$ невырашальнай брутальнасцю сітуацыі і свядома настаўляе на сябе смертаносную зрэнку рэвальвернага дула, то гэта, несумненна, смерць зусім не ананімная. Яна - мэтавая. I ў яе ёсць „імя”: пратэст супроць усё той жа безаблічнай, тупой і абыякавай да індывідуальнага чалавечага лёсу „камандзірскай свядомасці”.

Але калі, на самым апусканні фабульна-сюжэтнага фінальнага занавесу аповесці, чытачу даводзіцца легкамыснае меркаванне партызан з брыгады „Дзядзі Сашы” (яны, памятаем, нават не задаліся мэтаю праверыць, у чым там спра-

\footnotetext{
28 Ibid., s. 82.

${ }^{29}$ Ibid., s. 86

30 Ibid., s. 85 .
} 
ва), „іменная” пратэстная смерць тут жа зазнае тленны подых ананімнасці. Яна і насамрэч становіцца „,ананімнай” - праз накладанне аб'ёму чытацкага ведання і партызанскай ацэнкі стрэлу „ў тумане”: „Так, балуецца нехта... Дурань нейкі”з31. Выказванне таго, хто „ішоў за старшым”, - „дурань нейкі” - вяртае ў разрад ананімнасці: абясцэньвае ўсё, нават права смерці нешта сцвярджаць ці аспрэчваць. Цераз такую ацэнку ўсё жыццё чалавека, яго былое і яго будучыня („,рышачкаў плач"), атрымлівае бесцялесную і бяссутнасную далячынь гуманістычнай перспектывы.

А сам „туманны” кантрапункт чарговы раз у Быкава заплікваецца тугой пятлёй невырашальнай безнадзейнасці.

Аповесць, як бачна, сапраўды мае ўсе шанцы на тое, каб быць запатрабаванай чытацкай свядомасцю на розных гістарычных этапах свайго бытавання. Факт павышанага попыту, засведчаны Гродзенскай абласной бібліятэкай, мае рэальныя падставы. Нават больш за тое, аповесць падкрэслівае нейкі дадатковы момант у „пісьменніцкім імператыве” Васіля Быкава. Ён у тым, што спосаб расказвання - як спосаб філасофскага каменя, які дзіўна пераламляе звыклую ступень успрымальнасці. Мастацкі свет, у слове выяўлены, у Быкава іншасказальны і алегарычны, сапраўды „туманны”. Гэткая ж, наскрозь „туманная”, і граматыка быкаўскага наратыву, калі уусё чытаецца быццам бы паслядоўна, ад пачатку і да завяршэння гісторыі, а па сутнасці - цалкам наадварот: ад мнагазначнай семантыкі загалоўка, ад пэўнага канцавога моманту, ад трагедыі, завершанай і здзейсненай яшчэ перад першым апавядальным словам. Злачынства і пакаранне ў сацыяльным „тумане” не маюць неабходнасці да ўзаемнай сустрэчы паміж сабой, затое каты і іх ахвяры ў тым нялюдскім эксперыменце асуджаны на паслухмянае выкананне сваіх роляў i - што галоўнае! - выконваюць іх спраўна і да канца, надаючы апавядальнай інтэнцыі твора глыбокую ўнутраную і нязвычную ўласцівасць дэтэктыўнага парадку.

Дэтэктыву з мноствам зашыфраваных сюжэтных і змястоўных таямніц.

\section{Бібліяграфія}

Bykau Wasil, U tumanie. Apowiesci, Minsk: Mastackaja litaratura, 1989.

Bykau Wasil, Zbor tworau u 4-ch tamach, Minsk: Mastackaja litaratura, 1980-1982.

Kundera Milan, Iskusstwo romana, Sankt-Pietierburg: Azbuka-Attikus, 2014.

Szapran Siarhiej, Wasil Bykau - Aleś Adamowicz. Maładyja hady. Autabijagraficznyja dyjatogi W. Bykawa z A. Adamowiczam, ,Dziejasłou” 2014, 3, s. 183-200.

31 Ibid., s. 96. 


\section{Streszczenie}

Nie ulega wątpliwości, że Wasyl Bykau konsekwentnie ucieka w stronę tzw. prozy partyzanckiej. Z czego to wynika i w jaki sposób wpływa na kształt artystyczny utworu, oto temat artykułu prezentującego, na przykładzie powieści We mgle - wybrane chwyty narracyjne pisarza (semantyczny efekt pustego wyrazu i system kontrapunktów), tworzące de facto nowy typ konstrukcji tekstu artystycznego, określanej przez autora artykułu jako gramatyka intrygi narracyjnej.

Słowa kluczowe: Bykau, intryga narracyjna, proza, literatura białoruska, tekst, fabuła, koncept

\section{Рэзюме}

Відавочна, што Васіль Быкаў настойліва ажыццяўляе рэгулярныя „ўцёкі” у т.зв. „партызанскую” прозу. Чым тое можа быць вытлумачана, і якія эстэтычныя рашэнні 3 таго вынікаюць - цэнтральная праблема дадзенага артыкула. На прыкладзе аповесці У тумане разглядаюцца асобныя прыёмы наратыўнай тэхнікі пісьменіка. Найперш, эфект семантычны „чужога” слова і сістэмы контрапунктаў. Усё гэта аб'ядноўваецца у пэўны тып кіравання мастацкім тэкстам, што аўтар артыкула прапануе называць граматыкай наратыўнай інтрыгі.

Ключавыя словы: Быкаў, наратыўная інтрыга, проза, беларуская літаратура, тэкст, сюжэт, вымысел

\section{Summary}

Obviously, Vasil Bykov persistently carries out regular „escapes” in the so-called „guerrilla" prose. Haw it can be interpreted, and what aesthetic decisions are arising from consists the central issue of this article. So, the separate ways of narrative techniques of the writer's story In the fog are considered. The special attention is given to the semantic effect of ,stranger” words and system of kontrapunkts. All this is combined in a certain type of management of the artistic text, wich the author proposes to call as a grammar of narrative intrigue.

Key words: Bykov, narrative intrigue, prose, Belarusian literature, text, plot, fiction 